\title{
A Proposal for Evaluation Method of Energy Parameter Values in Cell Model for Thermodynamics of Refining Slag
}

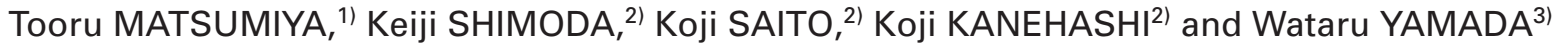 \\ 1) Technical Development Bureau, Nippon Steel Corporation, 20-1 Shintomi, Futtsu 293-8511 Japan. \\ 2) Advanced Technology Research Laboratories, Nippon Steel Corporation, 20-1 Shintomi, Futtsu $293-8511$ Japan. \\ 3) Kimitsu R\&D Laboratory, Nippon Steel Corporation, 1 Kimitsu, Kimitsu 299-1141 Japan.
}

(Received on January 19, 2007; accepted on March 12, 2007)

\begin{abstract}
In the cell model, a thermodynamic model of slag, the fractions of heterogeneous cation pairs are calculated which compose cells with an oxygen atom in between by the minimization of free energy of slag with energy parameters. On the other hand, by using NMR the fractions can be measured. Therefore, a new method can be proposed to evaluate the energy parameter values used in the cell model so that the calculated fractions in the slag with its minimum of free energy coincide with the measurement. The possibility of this evaluation method of energy parameter values was examined by the comparison of bridging oxygen/non-bridging oxygen (BO/NBO) ratio calculated by the cell model with energy parameter assessed elsewhere with measured $\mathrm{BO} / \mathrm{NBO}$ ratio by NMR. The $\mathrm{BO} / \mathrm{NBO}$ ratios of three $\mathrm{SiO}_{2}-\mathrm{Al}_{2} \mathrm{O}_{3}-\mathrm{CaO}$ slags with different basicities calculated by the use of cell model with energy parameter values assessed elsewhere were 42.5/57.5, 45/55 and 70/30, respectively. On the other hand, from ${ }^{17} \mathrm{OMAS}$ spectrum and ${ }^{27} \mathrm{Al} \rightarrow{ }^{17} \mathrm{O}$ CP/MAS spectrum of the same slags fully labeled and calcinated at 1600 centigrade degree, the ratios of $\mathrm{BO} / \mathrm{NBO}$ in the slags were determined as $48.5 / 51.5,42 / 58$ and 76/24, respectively. This agreement supports the energy parameter values assessed elsewhere and gives a good expectation to the proposed method.
\end{abstract}

KEY WORDS: thermodynamic model; slag; NMR; energy parameter; free energy.

\section{Introduction}

Since early 70's, thermodynamic models, thermodynamic equilibrium calculation methods of multi-component systems and graphic description of the calculated results have been developed for the calculation of phase diagrams. The thermodynamic models describe free energy of every phase as a function of its composition, temperature and pressure and are used for the equilibrium calculation of multi-component system at a given temperature, pressure and total compositions of the system. The cell model is one of a prominent thermodynamic model for slags and fluxes developed by H. Gaye and J. Welfringer. ${ }^{1)}$ In this model the number of each cell $R_{i j}$ in liquid oxide solutions, which consists of cation pair and an oxygen atom in between, is calculated so that the free energy of the solutions is minimized under a condition of the set values of the energy parameters, formation enthalpy of cells with heterogeneous cation pairs $W_{i j}$ and interaction energy between cells $E_{i j}$ with consideration of the entropy of mixing of the cells (Fig. 1). ${ }^{2)}$ The energy parameters are mainly accessed by the comparison of the calculated phase boundaries of multicomponent liquid slags and precipitating solid phases, and sulfide and phosphate capacities of slags by using the cell model for slags with observed ones. These values come from the result of equilibrium between slags and others, which are solid oxides and liquid steels. Therefore, if some evaluated values of the others are changed, the accessed energy parameters of slag must be re-assessed in order to satisfy the equilibrium relation with them.

On the other hand, since the chemical shift in nuclear magnetic resonance (NMR) spectrum of oxygen varies depending on what kinds of cations sit in both side of the oxygen, the relative number of each kind of cell can be measured from the intensity of the peak, which corresponds to the cell, in the oxygen NMR spectra. The present authors propose to evaluate the energy parameters values in the cell model more directly so that the calculated fraction of each cell in a slag at its minimum free energy state agrees the measured fraction by NMR spectra, in order to overcome the drawback in the rather indirect evaluation method of the parameters mentioned above.

In order to examine the prospective capability of the proposed "direct" evaluation method, firstly, the moles of every cells in three example slags with various basicities are calculated by the cell model using the energy parameters already assessed before, secondly, NMR measurements are conducted on the same three slags and, thirdly, the calculated and measured results are compared. At the end the results are discussed based on slag structure. In this paper, the "direct" evaluation method means the method, which utilizes the independent characteristics of molten slag only as 


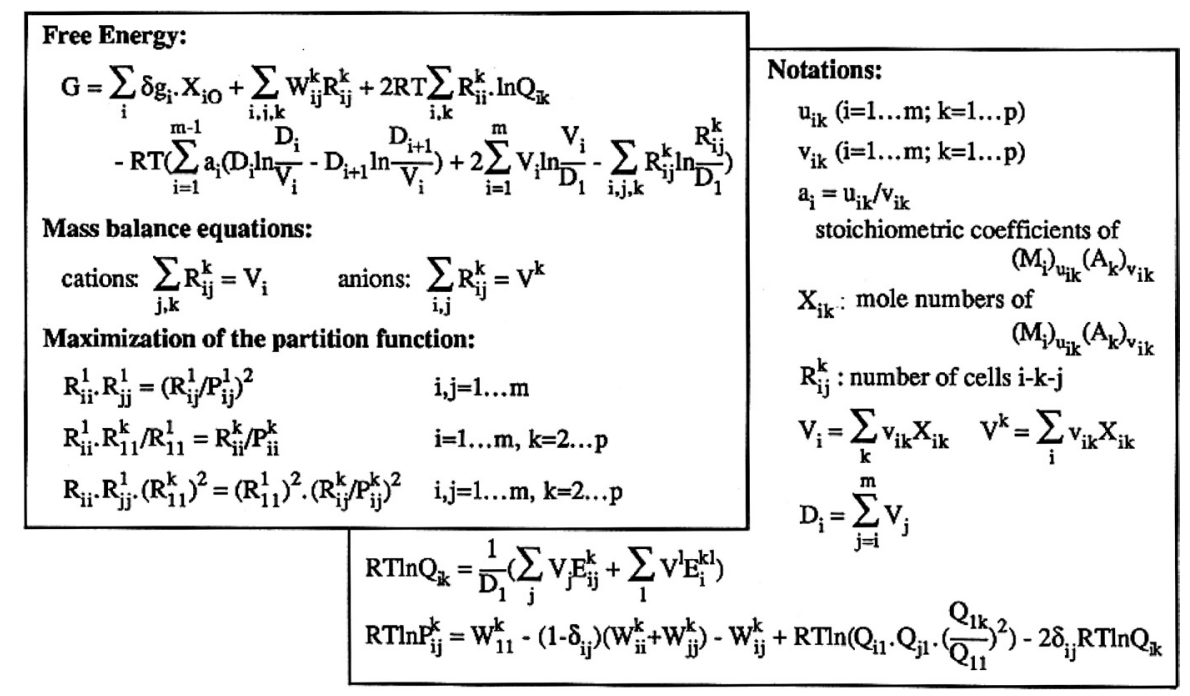

Fig. 1. Expressions of free energy in cell model. ${ }^{2)}$

Table 1. Chemical composition of slags.

\begin{tabular}{|c|c|c|c|}
\hline Slag & $\mathrm{SiO}_{2}$ & $\mathrm{Al}_{2} \mathrm{O}_{3}$ & $\mathrm{CaO}$ \\
\hline A & 34.9 mass $\%(0.360 \mathrm{~mol})$ & $16.2 \mathrm{mass} \%(0.099 \mathrm{~mol})$ & $48.9 \mathrm{mass} \%(0.541 \mathrm{~mol})$ \\
\hline B & 38.23 mass $\%(0.395 \mathrm{~mol})$ & $15.68 \mathrm{mass} \%(0.095 \mathrm{~mol})$ & $46.08 \mathrm{mass} \%(0.510 \mathrm{~mol})$ \\
\hline $\mathrm{C}$ & $57.4 \mathrm{mass} \%(0.601 \mathrm{~mol})$ & $15.9 \mathrm{mass} \%(0.098 \mathrm{~mol})$ & $26.8 \mathrm{mass} \%(0.301 \mathrm{~mol})$ \\
\hline
\end{tabular}

Table 2. Parameter values (cal/mol) $\left(W_{i j}^{k}\right.$ and $E_{i j}^{k}$ are indicated as $\mathrm{W}(\mathrm{i}-\mathrm{k}-\mathrm{J})$ and $\mathrm{E}(\mathrm{i}-\mathrm{k}-\mathrm{j})$, respectively.)

\begin{tabular}{l|l}
\hline $\mathrm{W}(\mathrm{Si}-\mathrm{O}-\mathrm{Al})=2000$ & $\mathrm{E}(\mathrm{Si}-\mathrm{Oal})=-3000$ \\
$\mathrm{~W}(\mathrm{Si}-\mathrm{O}-\mathrm{Ca})=-12500$ & $\mathrm{E}(\mathrm{Si}-\mathrm{O}-\mathrm{Ca})=-4500+7500 \mathrm{X}(\mathrm{SiO} 2)$ \\
$\mathrm{W}(\mathrm{Al}-\mathrm{O}-\mathrm{Ca})=-8500+3000 \mathrm{X}\left(\mathrm{Al}_{2} \mathrm{O}_{3}\right)$ & $\mathrm{E}(\mathrm{Al}-\mathrm{O}-\mathrm{Ca})=-5500-5000 \mathrm{X}\left(\mathrm{Al}_{2} \mathrm{O}_{3}\right)$ \\
\hline
\end{tabular}

Table 3. Calculated moles of various cells (moles and molar fractions).

\begin{tabular}{llllllll}
\hline slag & $(\mathrm{Si}-\mathrm{O}-\mathrm{Si})$ & $(\mathrm{Al}-\mathrm{O}-\mathrm{Al})$ & $(\mathrm{Si}-\mathrm{O}-\mathrm{Al})$ & $(\mathrm{Ca}-\mathrm{O}-\mathrm{Ca})$ & $(\mathrm{Si}-\mathrm{O}-\mathrm{Ca})$ & $(\mathrm{Al}-\mathrm{O}-\mathrm{Ca})$ & Total mole \\
\hline $\mathrm{A}$ & 0.228 & 0.158 & 0.092 & 0.002 & 0.894 & 0.184 & 1.558 \\
& $(0.146)$ & $(0.101)$ & $(0.059)$ & $(0.001)$ & $(0.574)$ & $(0.118)$ & $(1.000)$ \\
$\mathrm{B}$ & 0.300 & 0.160 & 0.107 & 0.001 & 0.871 & 0.146 & 1.586 \\
& $(0.189)$ & $(0.101)$ & $(0.067)$ & $(0.001)$ & $(0.550)$ & $(0.092)$ & $(1.000)$ \\
$\mathrm{C}$ & 0.803 & 0.153 & 0.258 & 0.000 & 0.540 & 0.061 & 1.797 \\
& $(0.447)$ & $(0.075)$ & $(0.143)$ & $(0.000)$ & $(0.301)$ & $(0.034)$ & $(1.000)$ \\
& & & & & & &
\end{tabular}

mentioned above, but does not mean a method where energy values are measured or calculated directly.

\section{Calculation by Cell Model}

The chemical compositions of test slags are listed Table 1. The moles of various cells in the slags were calculated by using the cell model with energy parameters listed in Table 2 , which are the same ones in the original cell model. The calculated moles are listed in Table 3. Since the slag alumina content is less than the composition of 'tectosilicate', where the charge of the modifier cation equals to aluminum atoms, aluminum atoms are in the silicate network ${ }^{4)}$ where oxygen in the cell ( $\mathrm{Al}-\mathrm{O}-\mathrm{Ca})$ had better be counted as bridging oxygen. Therefore, the $\mathrm{BO} / \mathrm{NBO}$ ratios in slag $\mathrm{A}$, $\mathrm{B}$ and $\mathrm{C}$ derived from Table 3 are approximately 42.5/57.5, $45 / 55$ and $70 / 30$, respectively.

\section{NMR Measurements}

${ }^{17} \mathrm{O}$ MAS spectrum and ${ }^{27} \mathrm{Al} \rightarrow{ }^{17} \mathrm{O} \mathrm{CP} / \mathrm{MAS}$ spectrum of the slag with same composition as test slag $\mathrm{B}$ full labeled and calcinated at 1600 centigrade degree were measured. The details of the NMR measurement are given in Ref. 3).

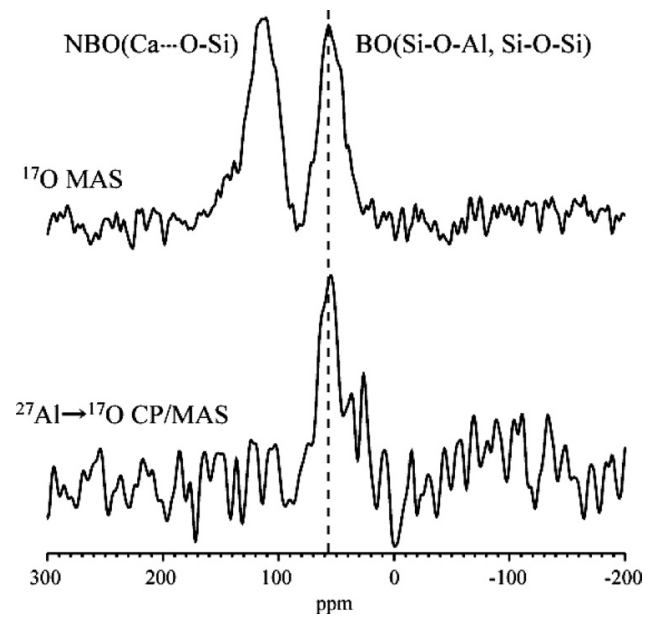

Fig. 2. ${ }^{17} \mathrm{O}$ MAS spectra and ${ }^{27} \mathrm{Al} \rightarrow{ }^{17} \mathrm{O} \mathrm{CP} / \mathrm{MAS}$ spectra of slag B.

The results are shown in Fig. 2. Since the peak in ${ }^{27} \mathrm{Al} \rightarrow{ }^{17} \mathrm{O}$ $\mathrm{CP} / \mathrm{MAS}$ spectrum can be assigned as $\mathrm{BO}$ peak, the other peak in ${ }^{17} \mathrm{O}$ MAS spectrum is assigned as NBO peak. From the relative intensities of these peaks in ${ }^{17} \mathrm{O}$ MAS spectrum the $\mathrm{BO} / \mathrm{NBO}$ ratio is measured to be approximately $42 / 58$. 

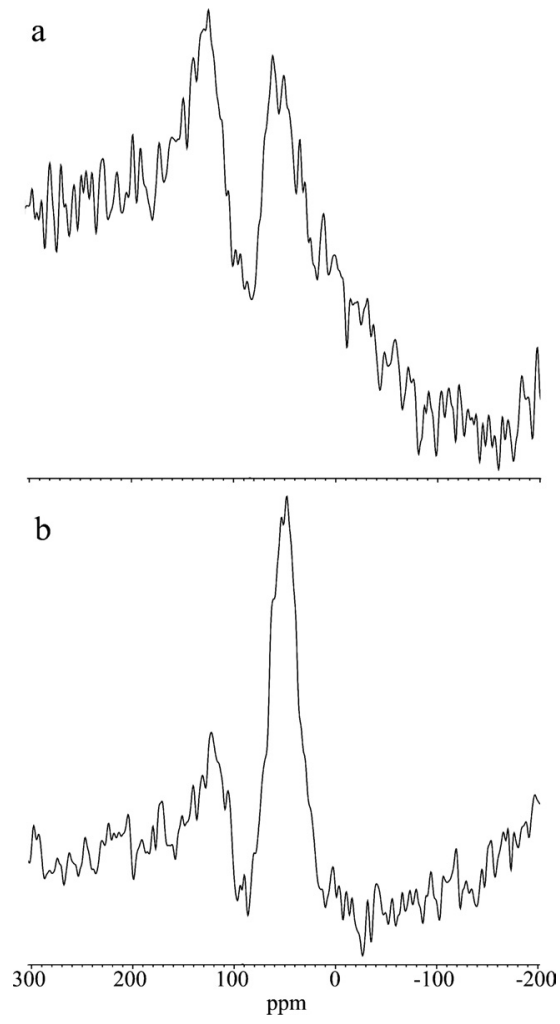

Fig. 3. ${ }^{17} \mathrm{O}$ MAS spectra of slag $\mathrm{A}(\mathrm{a})$ and $\mathrm{C}(\mathrm{b})$.

${ }^{17} \mathrm{O}$ MAS spectrum of slags with compositions of slags A and $\mathrm{C}$ full labeled and calcinated at 1600 -centigrade degree were also measured. The results are mentioned in Fig. 3. From the relative intensities of these peaks in ${ }^{17} \mathrm{O}$ MAS spectrum the $\mathrm{BO} / \mathrm{NBO}$ ratios in slags $\mathrm{A}$ and $\mathrm{C}$ are measured to be approximately $48.5 / 51.5$ and $76 / 24$, respectively.

\section{Discussions}

Although the moles of every cells could not be separately measured by NMR so far at this moment, the $\mathrm{BO} / \mathrm{NBO}$ ratio measured by NMR is in good agreement of the calculated one by the cell model with already assessed energy parameters. It means that NMR results also support the energy parameter values assessed before by the "indirect" method and that the "direct" evaluation method proposed here has possibility in its validity.

Since the slag alumina content is less than the composition of 'tectosilicate', where the charge of the modifier cation equals to aluminum atoms, aluminum atoms are in the silicate network ${ }^{4}$ as mentioned before. In one mole of $\mathrm{CaO} \cdot \mathrm{Al}_{2} \mathrm{O}_{3} 4$ moles of $\mathrm{BO}$ are included and any NBO is not included as shown in Fig. 4, the unit structure of $\mathrm{CaO} \cdot \mathrm{Al}_{2} \mathrm{O}_{3}$. That is, the same number of moles of $\mathrm{CaO}$ as the number moles of $\mathrm{Al}_{2} \mathrm{O}_{3}$ is used for forming network as shown in Fig. 4. The rest of $\mathrm{CaO}$ is considered to act as network modifier. Accordingly, one mole of rest $\mathrm{CaO}$ produces 2 moles of $\mathrm{NBO}$ and reduces 2 moles of $\mathrm{BO}$, which is made by 4 moles from each mole of $\mathrm{SiO}_{2}$. Based on this consideration, the total moles of $\mathrm{BO}$ and $\mathrm{NBO}$ in the slag $\mathrm{A}$ are 0.674 and 0.888 , those in slag $\mathrm{B}$ are 0.757 and 0.829 and those in slag $C$ are 1.391 and 0.401 , respectively. That is, $\mathrm{BO} / \mathrm{NBO}$ ratio is considered to be $43 / 57,48 / 52$ and $77 / 23$,

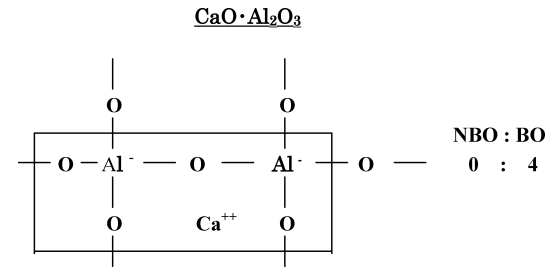

Fig. 4. Unit silicate structures of $\mathrm{CaO} \cdot \mathrm{Al}_{2} \mathrm{O}_{3}$ and moles of $\mathrm{NBO}$ and BO.

respectively. The calculated and measured $\mathrm{BO} / \mathrm{NBO}$ ratios both are close to these values, which means that measurement and calculation are both considered reasonable. However, it is only unreasonable that the measured $\mathrm{BO} / \mathrm{NBO}$ ratio in slag A was greater than that in slab B although slag A is more basic than slag B. This difference is considered to be within the limit of the quantitative accuracy of NMR from the $\mathrm{S} / \mathrm{N}$ ratio in the spectrum especially of slag $\mathrm{A}$. Therefore, the accuracy should be a little farther improved and the oxygen peak intensity of each cell should be separately evaluated in order to actually realize the proposed "direct" evaluation method of energy parameters in the cell model by NMR measurement in the future.

\section{Conclusions}

Proposed was a less indirect evaluation method of energy parameter values in the cell model for free energy of multicomponent slags. That is, the parameter values are evaluated so that calculated moles of various cells in slag by the cell model agree with the measured moles by NMR. By the use of chemical shift of oxygen peak of various cells in NMR spectrum, the peak of oxygen in various cells can be distinguished. For the verification of the proposed method the followings are obtained:

(1) The moles of various cells in three test slags consisting of $\mathrm{SiO}_{2}, \mathrm{Al}_{2} \mathrm{O}_{3}$ and $\mathrm{CaO}$ with various basicities in decreasing order are calculated by the cell model using the past assessed energy parameter values and $\mathrm{BO} / \mathrm{NBO}$ ratios based on the calculation were $42.5 / 57.5,45 / 55$ and $70 / 30$, respectively.

(2) The $\mathrm{BO} / \mathrm{NBO}$ ratio of the same slags were measured by NMR ${ }^{17} \mathrm{O}$ MAS spectrum and ${ }^{27} \mathrm{Al} \rightarrow{ }^{17} \mathrm{O} \mathrm{CP} / \mathrm{MAS}$ spectrum to be $48.5 / 51.5,42 / 58$ and $76 / 24$, respectively.

(3) From silicate structure consideration the ratio is estimated to be $43 / 57,48 / 52$ and $77 / 23$.

(4) Since the agreement among the above mentioned three, the capability of the presently proposed method is expected to be sound.

\section{REFERENCES}

1) H. Gaye and J. Welfringer: Proc. 2nd Int. Symp. on Metallurgical Slags and Fluxes, ed. by H. A. Fine and D. R. Gaskell, TMS-AIME, Warrendale, PA, (1984), 357.

2) H. Gaye, J. Lehmann, T. Matsumiya and W. Yamada: Proc. 4th Int. Symp. on Metallurgical Slags and Fluxes, Iron Steel Inst. Japan, Tokyo, (1992), 103.

3) K. Kanehashi, Y. Shimoikeda and K. Saito: Proc. 42nd NMR Conf. in Japan, The Nuclear Magnetic Resonance Society of Japan, Tokyo, (2003), 198.

4) B. O. Mysen: Structure and Properties of Silicate Melts, Elsevier, Amsterdam, (1988), 80. 